\title{
Linking Entrepreneurship Education With Entrepreneurial Intentions Of Technical University Students In Ghana: A Case of Accra Technical University
}

\author{
Cynthia Oduro-Nyarko (MBA) \\ Department of Secretaryship and Management Studies \\ Accra Technical University \\ Hannah Benedicta Taylor-Abdulai (PhD) \\ Department of Secretaryship and Management Studies \\ Accra Technical University \\ Emelia Ohene Afriyie (MBA) \\ Department of Secretaryship and Management Studies \\ Accra Technical University \\ Emelia Sarpong (MBA) \\ Department of Secretaryship and Management Studies \\ Accra Technical University \\ Christine Ampofo Ansah (MBA) \\ Department of Secretaryship and Management Studies \\ Accra Technical University
}

\begin{abstract}
Entrepreneurship education is essential to the development and promotion of entrepreneurial intentions among tertiary students. The aim of this study was to examine the relative importance of entrepreneurship education and entrepreneurial intentions among Technical University students, and to determine if there existed relationship between entrepreneurship education and entrepreneurial intentions of students in Technical Universities using Accra Technical University. The issue that the Technical Universities as a Technical, Vocational, Education and Training (TVET) institution is strategically involved in the attainment of the post-2015 SDGs in Ghana by creating an enabling environment (through teaching and learning) for business startups among its graduates due to the higher unemployment rate in Ghana. The study is quantitative in nature and adopts the descriptive survey approach by using structured questionnaire and interviews. Stratified and simple random sampling techniques were used to select students from final year classes based on the population from selected departments of the various Schools in the Technical University to form the sample size. In addition, all entrepreneurship lecturers were interviewed. Data analysis was by descriptive statistics using SPSS and regression analysis. The result suggests a positive relationship between entrepreneurship education and entrepreneurial intentions. For policy implication, a more systematic approach to entrepreneurship education is needed to improve the quality of teaching and learning of entrepreneurship in the Technical Universities to promote entrepreneurial intentions among students.
\end{abstract}

Keywords: Entrepreneurship Education, Entrepreneurial Intentions, Technical, Vocational, Education and Training (TVET), Technical Universities, Sustainable Development Goals 


\section{INTRODUCTION}

Entrepreneurship has been given much attention the world over as it plays an important role in economic growth and the creation of employment in a country. ( Hisrich et al., 2013) Also in recent times most countries recognize the importance of entrepreneurship education as there is now a paradigm shift from being employed to self-employment. Therefore policies regarding education and training are geared towards fostering entrepreneurial intentions of students (Lans et. al., 2008). A study conducted by Linan and Chen (2006) found out that one of the indicators of entrepreneurial intentions is entrepreneurship education in higher institutions. Wilson et al. (2007) opine that entrepreneurship education is a medium use to increase students' interest in entrepreneurship career as they found out that people are motivated to start-up business because they are exposed to entrepreneurship education. According to Thompson (2009), entrepreneurial intention is self-acknowledge conviction by a person that they intend to set up a new business venture and consciously plan to do so at some point in the future. In a study conducted by Owusu-Ansah (2004), it was found out that entrepreneurship education motivates and increases the tertiary students' aspirations in starting their own business. In Sri Lanka, Kumara 2012 confirmed in a study that students who receive entrepreneurship education have positive attitudes and beliefs towards self-employment; thus there is a positive relationship between entrepreneurship education and entrepreneurial intentions. Entrepreneurial action is most often intentional, and intentions capture the motivational factors that influence a behavior: they are indications of how hard people are willing to try, of how much of an effort they are planning to exert to perform the behavior. As a general rule, the stronger the intention to engage in a behavior, the more likely should be its performance. (Hisrich et al., 2008)

Since entrepreneurship education influences entrepreneurial intentions most countries would like to encourage entrepreneurship amongst tertiary students to strengthen their willingness to undertake some kind of enterprising project to reduce the burden of unemployment on government. In the US, more colleges and universities have discovered that entrepreneurship is an extremely popular course of today (Zimmerer \& Scarborough, 2008) and Ghana is no exception. In Ghana the advent of youth entrepreneurship is being encouraged by the government through funding, TVET support and other non-governmental organizations to get more tertiary school leavers to develop entrepreneurial intention to start their own businesses after school. (UNESCO, 2002; Anamoah-Mensah, 2004). It has been realized that in higher education environment, entrepreneurial teaching and learning is a tool for strengthening enterprising behavior of students. Entrepreneurial teaching involves the transfer of entrepreneurial attitudes and skills development relevant to personal characteristics and the specific training of technical and business skills for creating new firms. This is in line with the aims of both the Technical Universities and Technical and Vocational Education and Training (TVET). The purpose of setting up the Technical Universities is to train middle level manpower graduates in technical and skills development. The skill they so develop at the Technical Universities, the knowledge they acquire through entrepreneurship education and the contacts they have with industries through industrial attachments will encourage them to undertake enterprising ventures to curb unemployment in the economy. In Ghana, the unemployment rate according the Ghana Statistical Services now stands at an average of 8.82 percent from 2001 until 2013. This show an unprecedented high rate of $12.90 \%$ in 2005 and a record low of $15.20 \%$ in 2013. As the 2010 population and housing census (GSS, 2010) currently put unemployment rate among the youth aged between $15-24$ as $16.4 \%$ for males and then $16.7 \%$ for females, it is anticipated that through entrepreneurship education at the Technical 
universities the Sustainable Development Goal (4) to ensure inclusive and equitable quality education and promote lifelong learning opportunities for all will be achieved.

Gibben, (2010) argue that entrepreneurship education is made up of entrepreneurial teaching and learning. Entrepreneurial teaching involves the transfer of entrepreneurial attitudes and skills development relevant to personal characteristics and the specific training of technical and business skills for creating new firms. With the continuous increase in unemployment rate, a further validation on quantitative information on students profile about their entrepreneurial intention is needed. Hence this study was undertaken to fill in this gap. The objective of the study is to add to the body of knowledge in the area of entrepreneurship by examining the relationship between entrepreneurship education and entrepreneurial intentions of students in higher institutions, precisely Technical Universities in Ghana. Specifically, the research looked at the following objectives: analyze the effectiveness of entrepreneurship educations in the Technical Universities, investigate the effect of entrepreneurship education on the entrepreneurial intentions of the students and to determine the relationship between their entrepreneurial intentions and the readiness to create a venture.

\section{METHODS}

The study used descriptive survey design to examine the effect of entrepreneurship education on the entrepreneurial intention of Accra Technical University students. The population for the study comprised all final year students in the Department of Secretaryship and Management Studies. The total population of both final year full-time and part-time constitute 363 students. A sample of 130 respondents was selected for the survey in the Department. Structured questionnaire with close ended questions was used to collect primary data from both full-time and part-time students. The study used the stratified and simple random sampling technique. Descriptive statistics was the medium used for analysis of quantitative data. Inferential statistics tools including chi-square test, KMO for factor analysis which involved the testing of hypotheses, identifying causality and reliability was also used.

The research tried to answer the following questions: How effective is entrepreneurship education in the Technical Universities? What is the effect of entrepreneurship education on the entrepreneurial intentions of students in the Technical Universities? Is there a relationship between the students' entrepreneurial intentions and their readiness to create a venture?

\section{RESULTS AND DISCUSSION}

This section presents the demographic profiles of the 128 respondents contacted. Of the respondents, $6.3 \%$ ( 8) were male, while 93.8\% (120) were female.

In the distribution of age, $69.5 \%$ ( 89) were within 20-25year, $25.8 \%$ ( 33) were within 26-30 year, while $3 \%(5)$ were within the age group 31-35. There was one respondent who age was between 36-40 years (0.8\%). From the analyzed data the subjects' age ranged from 25 and 35 are the most respondent who participated in this study.

In terms of level of students and their department, it was released that all the students were in the Secretaryship and Management Studies department and were all in level 300. 
Oduro-Nyarko, C., Taylor-Abdulai, H. B., Ohene Afriyie, E., Sarpong, E., \& Ampofo Ansah, C. (2017). Linking Entrepreneurship Education With Entrepreneurial Intentions Of Technical University Students In Ghana: A Case Of Accra Technical University. Archives of Business Research, 5(6),

Table 1

Demographic profile of respondents

\begin{tabular}{llcc}
\hline Demographics & Categories & Frequency & Percent \\
& & & (\%) \\
\hline Gender & Male & 8 & 6.3 \\
& Female & 120 & 93.8 \\
Age & $20-25$ & & 69.5 \\
& $26-30$ & 89 & 25.8 \\
& $31-35$ & 33 & 3.9 \\
Level Of Students & $36-40$ & 5 & 0.8 \\
Department & 300 & 1 & 100 \\
& Sec \& Mgt studies & 128 & 100 \\
\hline
\end{tabular}

Table 2, provides descriptive statistics for all the items. The result shows that entrepreneurship as a course of study in the polytechnic is very important that to be encourage in the institution. It had an estimated average of $(\bar{x}=4.77)$ and standard deviation of $(\sigma=0.61)$. Respondents agreed to the fact that the course content is enough to motivate them to become an entrepreneurs $(\bar{x}=4.24)$, though it had a high value of the $(\sigma=1.07)$. Most of the respondents agreed that the course has improved their understanding of becoming entrepreneurs, $(\bar{x}=4.48)$, with $\sigma=0.81$. The result also shows that Entrepreneurship education is important in today's society as it had an $(\bar{x}=4.76)$ and a $(\sigma=0.68)$. Respondents (students) rated the Entrepreneurship education in tertiary education leads to more start-up ventures and more economic growth high with an $(\bar{x}=4.52)$ and a $(\sigma=0.71)$. This is an indication that entrepreneurship education is a key for development for students to start their own business. Unemployment rate could be reduced when entrepreneurship education is encourage $(\bar{x}=4.66)$ and $\mathrm{a}(\sigma=0.80)$.

The overall statistics $((\bar{x}=4.34)$ with a low dispersion of $(\sigma=0.460)$.this is an indication that respondents agree to all the items to be positively to establish their own business in other that there will be low unemployment rate in the country. This shows that there is significant relationship between entrepreneurship education and intention to become entrepreneur. 
Table2

Descriptive statistics of the items

\begin{tabular}{|c|c|c|c|}
\hline $\mathrm{S} / \mathrm{N}$ & Items & $\operatorname{Mean}(\bar{X})$ & Std. Deviation $(\sigma)$ \\
\hline 1 & $\begin{array}{l}\text { Entrepreneurship as a course of study in the polytechnic } \\
\text { is important* }\end{array}$ & 4.77 & 0.61 \\
\hline 2 & $\begin{array}{l}\text { The course content is enough to motivate me to become } \\
\text { an entrepreneur* }\end{array}$ & 4.24 & 1.07 \\
\hline 3 & $\begin{array}{l}\text { The course has improved my understanding of concepts } \\
\text { in entrepreneurship* }\end{array}$ & 4.48 & 0.81 \\
\hline 4 & $\begin{array}{l}\text { Improved my ability to think strategically when it comes } \\
\text { to making business decisions as a result of the } \\
\text { entrepreneurship course* }\end{array}$ & 4.34 & 0.76 \\
\hline 5 & $\begin{array}{l}\text { Motivated to do more than the minimum requirements } \\
\text { for this course because I want to be an entrepreneur* }\end{array}$ & 4.32 & 0.84 \\
\hline 6 & $\begin{array}{l}\text { Entrepreneurship education is important in today's } \\
\text { society* }\end{array}$ & 4.76 & 0.68 \\
\hline 7 & $\begin{array}{l}\text { Entrepreneurship education in tertiary education leads } \\
\text { to more start-up ventures and more economic growth* }\end{array}$ & 4.52 & 0.71 \\
\hline 8 & $\begin{array}{l}\text { The entrepreneurship course should be more than one } \\
\text { academic year* }\end{array}$ & 4.23 & 1.01 \\
\hline 9 & Content with course delivery* & 4.18 & 0.84 \\
\hline 10 & Rate the course delivery* & 4.46 & 0.92 \\
\hline 11 & Entrepreneurship education will reduce unemployment* & 4.66 & 0.80 \\
\hline 12 & $\begin{array}{l}\text { Entrepreneurship education should be compulsory in all } \\
\text { tertiary institutions }\end{array}$ & 4.42 & 0.99 \\
\hline 13 & I am ready to be an entrepreneur* & 4.45 & 0.80 \\
\hline 14 & $\begin{array}{l}\text { I will make every effort to start and run my own } \\
\text { business* }\end{array}$ & 4.48 & 0.78 \\
\hline 15 & $\begin{array}{l}\text { If I had the opportunity and resources, I would like to } \\
\text { start a business* }\end{array}$ & 4.66 & 0.70 \\
\hline 16 & I am determine to create a firm in the future* & 4.59 & 0.69 \\
\hline 17 & I have got the intention to start a firm someday* & 4.48 & 0.75 \\
\hline 18 & I have got the intention to start a firm right after school & 3.69 & 1.11 \\
\hline 19 & $\begin{array}{l}\text { I have not thought of immediately starting a business on } \\
\text { my own }\end{array}$ & 2.67 & 1.40 \\
\hline 20 & $\begin{array}{l}\text { Being an entrepreneur would entail great satisfaction for } \\
\text { me* }\end{array}$ & 4.46 & 0.98 \\
\hline & OVERALL & 4.34 & 0.460 \\
\hline
\end{tabular}

\section{*Statement means agreement}

The figure 1 shows that about $88 \%$ of the respondents agreed that entrepreneurship education is relevant to students $5.92 \%$ of the respondents were neutral in their response and about $5.6 \%$ said they disagree that the entrepreneurship education in the polytechnic is relevant to them as students. This is an indication that majority of the students like the course content and are motivated to by the course to be able to do their own business. 


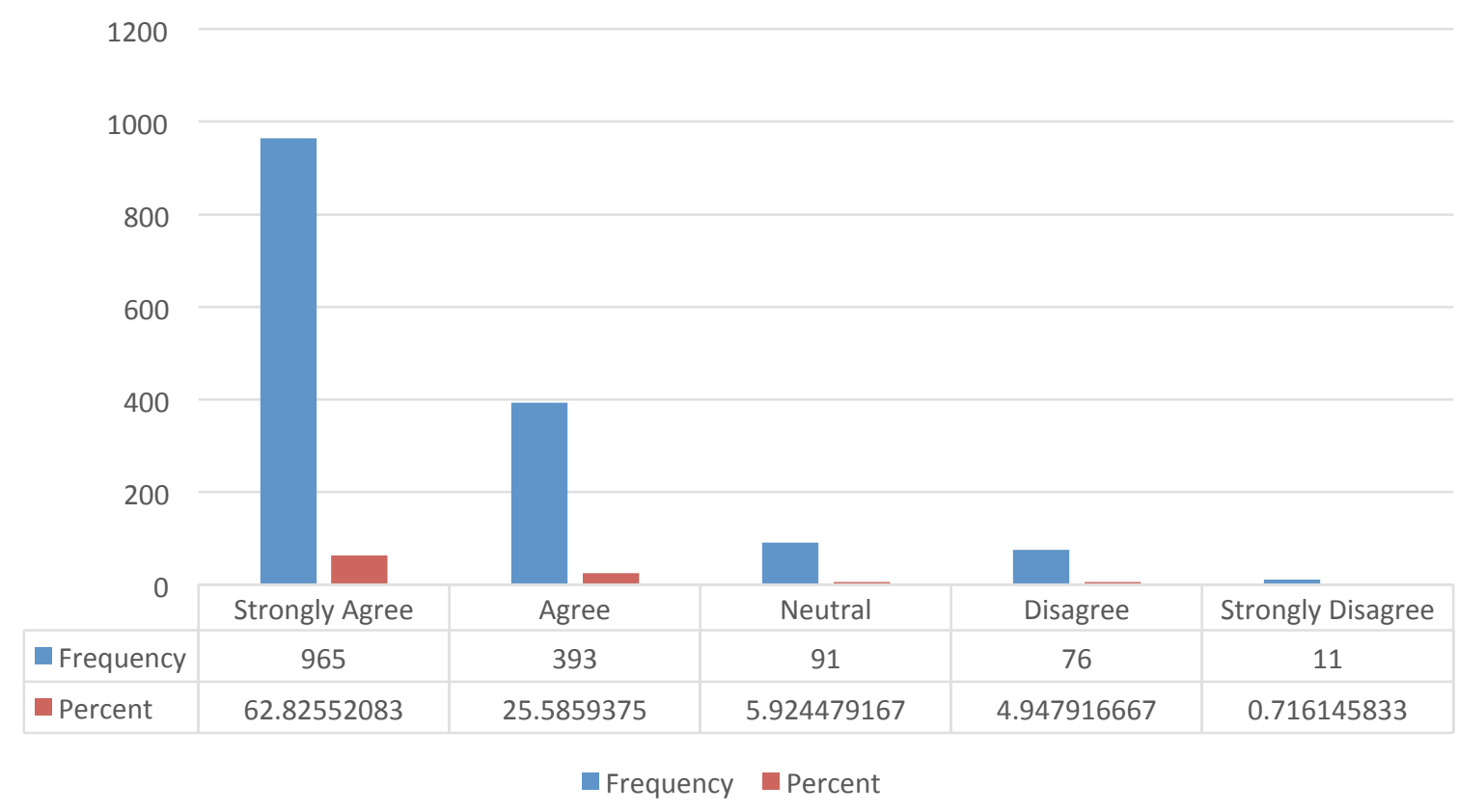

Figure 1: Students views on the relevance of entrepreneurship education

The figure 2 below shows the intent by respondents (students) whether they will become entrepreneurs not necessary depending on government for jobs. Comparing the rating on the relevance of entrepreneurship education by the students and their intention to become future entrepreneurs, there is no thought in their minds that majority agreed to that they want to do their own work as they rated the intentions about $79.8 \%$ support. About $11.52 \%$ of the respondents disagree that they would become entrepreneurs.

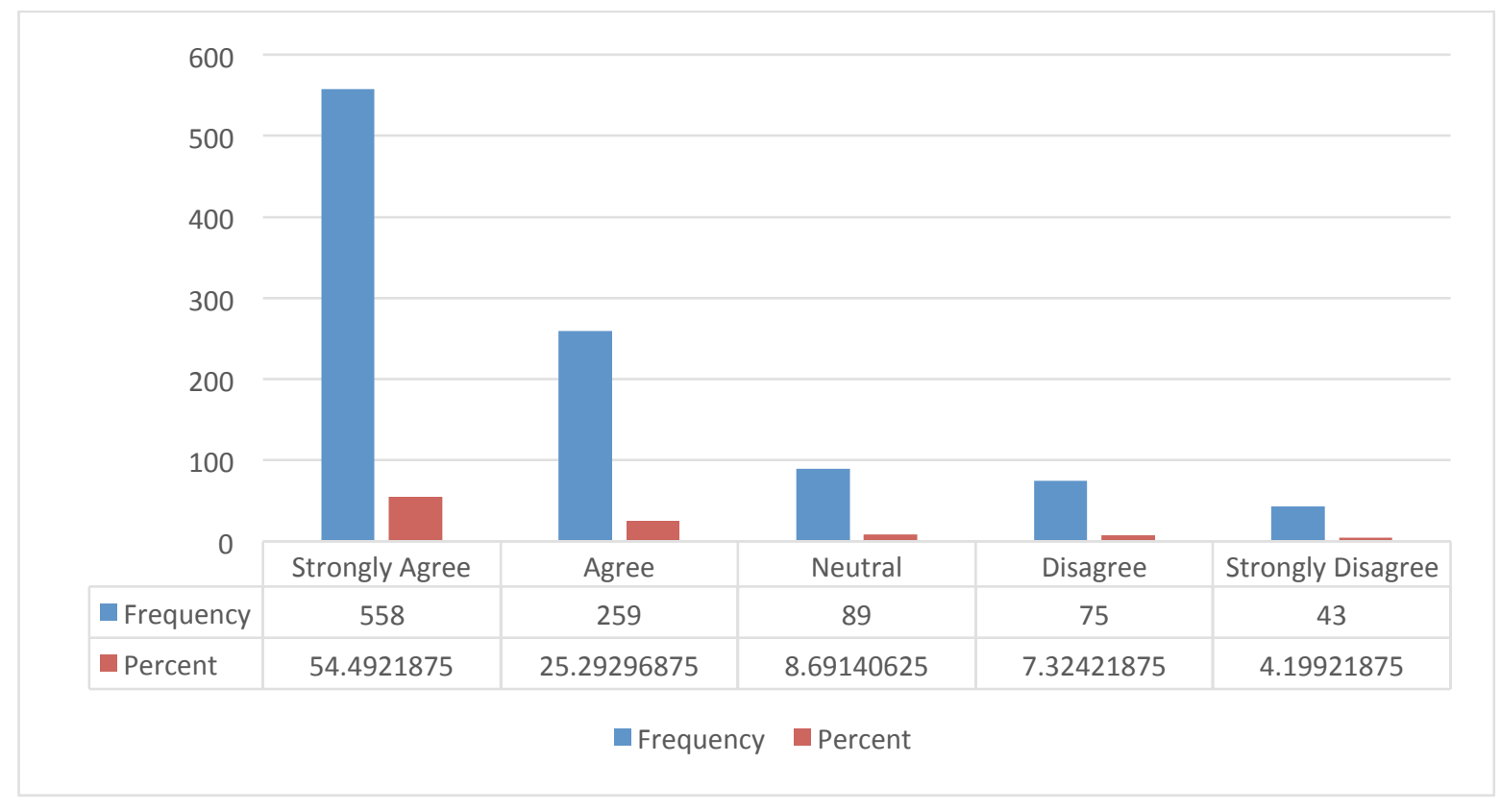

Figure 2: Students response on the intention to become entrepreneurs 


\section{TESTING OF THE HYPOTHESIS}

\section{Hypothesis 1: Entrepreneurship education significantly influence students to become entrepreneurs}

The data were subjected to factor analysis using Principal Axis Factoring. The KMO values for the individual items were above 0.5 and the Kaiser-Meyer -Olkin measure was 0.828 indicating that the data were sufficient for EFA as indicated by Kaiser (1974). The Bartlett test of Sphericty $\chi^{2}(190)=861.578, p$-value $<0.001$ showed that there were patterned relationship between the items. This means that entrepreneurship education has very good impact on the students to become entrepreneurs in future, therefore the hypothesis support the claim that, entrepreneurship education in the Polytechnic level significantly influence students to be entrepreneurs in their own society they find themselves. The correlation between the two construct also indicate that there is some level of relationship between the two constructs (the entrepreneurship education and the intention to become an entrepreneur)

This is very good direction to go, that is to solve unemployment related issues in the country. Tertiary education must also focus on the need to encourage students to be entrepreneurs to reduce the burden on government by providing job for graduate.

The result in table 3 shows the structure matrix which shows the correlations of the item with each of the factors. The factor 2 correlate very well with items 2 (the course content is enough to motivate me to become an entrepreneur), 3(The course has improved my understanding of concepts in entrepreneurship) and item 4(Improved my ability to think strategically when it comes to making business decisions as a result of the entrepreneurship course) with $0.661,0628$ and 0.651 respectively. Factor 1 also correlate well with 13 items as highlighted in the table 3 below. 
Oduro-Nyarko, C., Taylor-Abdulai, H. B., Ohene Afriyie, E., Sarpong, E., \& Ampofo Ansah, C. (2017). Linking Entrepreneurship Education With Entrepreneurial Intentions Of Technical University Students In Ghana: A Case Of Accra Technical University. Archives of Business Research, 5(6),

Table 3 Structure Matrix

\begin{tabular}{|c|c|c|c|}
\hline & \multirow{2}{*}{ Item } & \multicolumn{2}{|c|}{ Factors } \\
\hline $\mathrm{S} / \mathrm{N}$ & & 1 & 2 \\
\hline 1 & Entrepreneurship as a course of study in the polytechnic is important & 0.288 & 0.309 \\
\hline 2 & The course content is enough to motivate me to become an entrepreneur & 0.113 & 0.661 \\
\hline 3 & $\begin{array}{l}\text { The course has improved my understanding of concepts in } \\
\text { entrepreneurship }\end{array}$ & 0.415 & 0.628 \\
\hline 4 & $\begin{array}{l}\text { Improved my ability to think strategically when it comes to making } \\
\text { business decisions as a result of the entrepreneurship course }\end{array}$ & 0.403 & 0.651 \\
\hline 5 & $\begin{array}{l}\text { Motivated to do more than the minimum requirements for this course } \\
\text { because I want to be an entrepreneur }\end{array}$ & 0.641 & 0.374 \\
\hline 6 & Entrepreneurship education is important in today's society & 0.544 & 0.252 \\
\hline 7 & $\begin{array}{l}\text { Entrepreneurship education in tertiary education leads to more start-up } \\
\text { ventures and more economic growth }\end{array}$ & 0.514 & 0.376 \\
\hline 8 & The entrepreneurship course should be more than one academic year & 0.495 & 0.341 \\
\hline 9 & Content with course delivery & 0.483 & 0.416 \\
\hline 10 & Rate the course delivery & 0.535 & 0.395 \\
\hline 11 & Entrepreneurship education will reduce unemployment & 0.49 & 0.251 \\
\hline 12 & $\begin{array}{l}\text { Entrepreneurship education should be compulsory in all tertiary } \\
\text { institutions }\end{array}$ & 0.455 & 0.227 \\
\hline 13 & I am ready to be an entrepreneur & 0.58 & 0.421 \\
\hline 14 & I will make every effort to start and run my own business & 0.474 & 0.188 \\
\hline 15 & If I had the opportunity and resources, I would like to start & 0.625 & 0.098 \\
\hline 16 & I am determine to create a firm in the future & 0.709 & 0.104 \\
\hline 17 & I have got the intention to start a firm some day & 0.687 & 0.213 \\
\hline 18 & I have got the intention to start a firm right after school & 0.501 & 0.406 \\
\hline 19 & I have not thought of immediately starting a business on my own & 0.034 & 0.381 \\
\hline 20 & Being an entrepreneur would entail great satisfaction for me & 0.572 & 0.382 \\
\hline
\end{tabular}

Factor: 1(Relevance of entrepreneurship education), 2 (intention to become entrepreneur)

The exploratory factor analysis provided a correlation between the two factors a value of 0.454, which is quite good relationship between the two factors, the relevance of entrepreneurship education and the intention to be an entrepreneur. This relationship is positively good. Meaning that entrepreneurship education can influence the intention to become an entrepreneur about $45 \%$, which is a positive sign

Students in the Technical Universities believe that education on entrepreneurship can have much impact to become successful in their society when the course content is updated often to meet the changing economy they find themselves in. the students also believe that they are motivated by the nature of structure of course and as a result they would challenge themselves to become future entrepreneurs in their society to help in the development of their society. Based on the result generated there is an indication that about $79 \%$ of the respondents would like to be entrepreneurs

\section{CONCLUSIONS AND RECOMMENDATIONS}

The study had look at the relationship between entrepreneurship education and entrepreneurial intentions of students of Accra Technical University. From the data gathered from the study, the following conclusion has been drawn. In the cause of the study it was 
recognized that most students have the desire to start-up their own business as a result of knowledge acquired in entrepreneurship education.

The findings have both theoretical and practical considerations for the Technical Universities, policy makers, students and researchers. The result shows that a more systematic approach to entrepreneurship education should be adhere to improve the quality of teaching and learning of entrepreneurship in the Technical Universities to promote entrepreneurial intentions.

\section{References}

Anamoah-Mensah, J. (2004). Vocation/Technological Education for Accelerated Wealth Creation: Critical Issues Facing the Nation. Paper presented at the $56^{\text {th }}$ New Year School. Conference organized by the Institute of Adult Education at the University of Ghana, 30 December, 2001.

Cerny, C.A., \& Kaiser, H.F. (1977). A study of a measure of sampling adequacy for factor-analytic correlation matrices. Multivariate Behavioral Research, 12(1), 43-47.

Ghana Statistical Service (2012): Population and Housing Census. Retrieved from www.stastsghana.gov.gh; February 14, 2013 - Producer(s) Ghana Statistical Service - Ministry of Finance and Economic Planning.

Gibben, A. (2010). ETF Pilot Project: Http://www.etf.euro pa.eu/.../

Hisrich, R., Peters, M., \& Shepherd, D. (2013). Entrepreneurship (9th ed.). New York: McGraw-Hill. NY

Kaiser-Meyer-Olkin (KMO) Test for Sampling Adequacy was last modified: December 3rd, 2016 by Andale

Kumara, Samantha P. A. P. (2012), Undergraduates intention towards entrepreneurship: empirical evidence fromSri Lanka, Journal of Enterprising Culture: 20(1), 105-118

Lans, T. W., H., Hulsink, H., Baert, and M. Mulder. 2008. Entrepreneurship education and training in the small business context: Insights from the competence-based approach. Journal of Enterprising Culture 16 (4): $363-83$.

Liñán, F. (2008). Skill and value perceptions: How do they affect entrepreneurial intentions? International Entrepreneurship and Management Journal, 4(3), 257-272.

Liñán, F. \& Chen, Y.W. (2006). Development and cross-cultural application of a specific instrument tomeasure entrepreneurial intentions. Entrepreneurship Theory and Practice, 33(3), 593-617.

Owusu-Ansah, W. A. (2004). The Impact of entrepreneurship education on career intentions and aspiration of tertiary students in Ghana. A paper presented at the 49th World Conference of International Council for Small Business, 20th to 23rd June 2004, Johannesburg, South Africa

Thompson, E.R. (2009). Individual Entrepreneurial Intent; Construct Classification and Development of an Intentionally Reliable metric

UNESCO \& ILO (2002). Technical and vocational education and training for the twenty first century. Geneva: UNESCO

Wilson, F., Kickul, J. \& Marlino, D (2007). Gender, entrepreneurial self-efficacy, and entrepreneurial career intentions: Implication of entrepreneurship education, Entrepreneurship: Theory and practice 406.

Zimmerer, T.W. \& Scarborough, N.M., (2008). Essentials of Entrepreneurship and Small Business Management. (5 ${ }^{\text {th }}$ ed.) Pearson Education, Inc., Upper Saddle River, New Jersey 